University of Montana

ScholarWorks at University of Montana

8-2006

\title{
Monitoring Low Density Avian Populations: An Example using Mountain Plovers
}

Victoria J. Dreitz

University of Montana - Missoula, victoria.dreitz@cfc.umt.edu

Paul M. Lukacs

Colorado State University - Fort Collins

Fritz L. Knopf

Fort Collins Science Center, Fort Collins, co

Follow this and additional works at: https://scholarworks.umt.edu/wildbio_pubs

Part of the Life Sciences Commons

Let us know how access to this document benefits you.

\section{Recommended Citation}

Dreitz, Victoria J.; Lukacs, Paul M.; and Knopf, Fritz L., "Monitoring Low Density Avian Populations: An Example using Mountain Plovers" (2006). Wildlife Biology Faculty Publications. 54.

https://scholarworks.umt.edu/wildbio_pubs/54

This Article is brought to you for free and open access by the Wildlife Biology at ScholarWorks at University of Montana. It has been accepted for inclusion in Wildlife Biology Faculty Publications by an authorized administrator of ScholarWorks at University of Montana. For more information, please contact scholarworks@mso.umt.edu. 


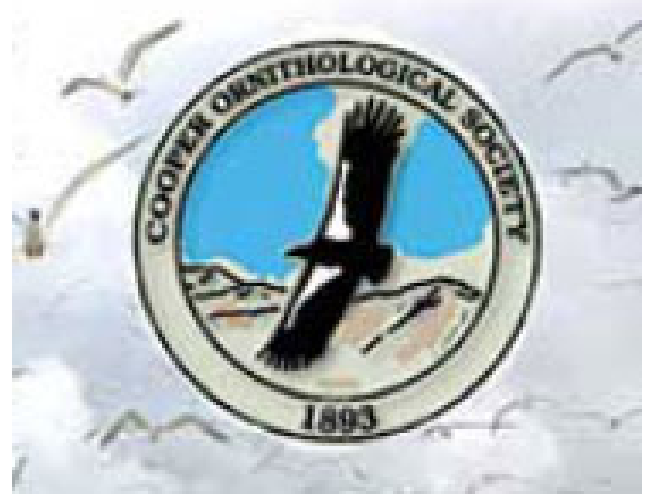

Monitoring Low Density Avian Populations: An Example using Mountain Plovers / Programas de Monitoreo de Poblaciones de Aves de Baja Densidad: Un Ejemplo Basado en Charadrius montanus

Author(s): Victoria J. Dreitz, Paul M. Lukacs and Fritz L. Knopf

Source: The Condor, Vol. 108, No. 3 (Aug., 2006), pp. 700-706

Published by: University of California Press on behalf of the Cooper Ornithological Society

Stable URL: http://www.jstor.org/stable/4151089

Accessed: 19/11/2013 18:00

Your use of the JSTOR archive indicates your acceptance of the Terms \& Conditions of Use, available at http://www.jstor.org/page/info/about/policies/terms.jsp

JSTOR is a not-for-profit service that helps scholars, researchers, and students discover, use, and build upon a wide range of content in a trusted digital archive. We use information technology and tools to increase productivity and facilitate new forms of scholarship. For more information about JSTOR, please contact support@jstor.org.

University of California Press and Cooper Ornithological Society are collaborating with JSTOR to digitize, preserve and extend access to The Condor. 


\title{
SHORT COMMUNICATIONS
}

\section{MONITORING LOW DENSITY AVIAN POPULATIONS: AN EXAMPLE USING MOUNTAIN PLOVERS}

\author{
Victoria J. Dreitz ${ }^{1,4}$, Paul M. LuKaCs ${ }^{2}$, And Fritz L. KNOPF ${ }^{3}$ \\ ${ }^{I}$ Colorado State University, Colorado Natural Heritage Program, 8002 Campus Delivery, Fort Collins, \\ CO 80523 \\ ${ }^{2}$ Colorado Cooperative Fish and Wildlife Research Unit, Department of Fishery and Wildlife Biology, \\ 1484 Campus Delivery, Colorado State University, Fort Collins, CO 80523 \\ ${ }^{3}$ U.S. Geological Survey, Fort Collins Science Center, 2150 Centre Ave., Building C, Fort Collins, CO 80526
}

\begin{abstract}
Declines in avian populations highlight a need for rigorous, broad-scale monitoring programs to document trends in avian populations that occur in low densities across expansive landscapes. Accounting for the spatial variation and variation in detection probability inherent to monitoring programs is thought to be effort-intensive and timeconsuming. We determined the feasibility of the analytical method developed by Royle and Nichols (2003), which uses presence-absence (detection-nondetection) field data, to estimate abundance of Mountain Plovers (Charadrius montanus) per sampling unit in agricultural fields, grassland, and prairie dog habitat in eastern Colorado. Field methods were easy to implement and results suggest that the analytical method provides valuable insight into population patterning among habitats. Mountain Plover abundance was highest in prairie dog habitat, slightly lower in agricultural fields, and substantially lower in grassland. These results provided valuable insight to focus future research into Mountain Plover ecology and conservation.
\end{abstract}

Key words: abundance, Charadrius montanus, detection probability, estimation, monitoring, Mountain Plover.

Programas de Monitoreo de Poblaciones de Aves de Baja Densidad: Un Ejemplo Basado en Charadrius montanus

Manuscript received 22 December 2005; accepted 18 April 2006.

${ }^{4}$ Present address: Colorado Division of Wildlife, 317 West Prospect Road, Fort Collins, CO 80526. E-mail: Victoria.Dreitz@state.co.us
Resumen. Las disminuciones en las poblaciones de aves resaltan la necesidad de implementar programas rigurosos de monitoreo de gran escala para documentar las tendencias de las poblaciones en especies que se encuentran a bajas densidades en paisajes amplios. Se cree que realizar correcciones para tener en cuenta la variación espacial y la variación en la probabilidad de detección requiere de mucho esfuerzo y tiempo. En este estudio determinamos la factibilidad del método analítico desarrollado por Royle y Nichols (2003), que utiliza datos de presencia $\mathrm{y}$ ausencia (detección y no detección) recolectados en el campo para estimar la abundancia de Charadrius montanus por unidad de muestreo en campos agrícolas, pastizales y ambientes ocupados por perros de las praderas en el este de Colorado. Los métodos de campo fueron fáciles de implementar, y los resultados sugieron que este método analítico provee información valiosa en cuanto a los patrones poblacionales en los distintos hábitats. La abundancia de $C$. montanus fue máxima en los ambientes ocupados por perros de las praderas, un poco menor en campos agrícolas y sustancialmente menores en pastizales. Estos resultados proveen información básica que resulta valiosa para enfocar las investigaciones futuras sobre la ecología y conservación de $C$. montanus.

Evidence of large-scale declines in avian populations highlights the need for extensive and rigorous monitoring programs to document species occurrence and to detect population changes. Numerous programs promote long-term, large-scale studies to document, measure, and monitor avian populations (e.g., North American Breeding Bird Survey, Monitoring Avian Productivity and Survivorship, North American Waterfowl Management Plan, North American Bird Conservation Initiative), especially 
for species believed to be at risk. All monitoring programs face two important sources of variation that must be dealt with in program design: spatial variation in abundance and detectability (Thompson 1992, Lancia et al. 1994, Yoccoz et al. 2001, Pollock et al. 2002). Spatial variation is problematic for population estimation in the typical situation where investigator(s) cannot apply survey or monitoring techniques over the entire area to which inference is to be drawn. Incomplete detectability refers to the fact that few, if any, species are so conspicuous that they are always detected during surveys even when present (Pollock et al. 2002, Royle and Nichols 2003, MacKenzie et al. 2004). Thus, monitoring programs must incorporate methods of estimating or removing effects of incomplete detectability. When this is done properly, it can be assumed that estimated changes in animal abundance or density reflect true changes. Methods for estimating detectability have been well documented and fall broadly into a probabilistic framework. These estimation methods are often used in detailed experiments or small-scale investigations, but are not as widely used for large-scale monitoring programs because they are viewed as too intensive or time-consuming (Royle and Nichols 2003).

The use of presence-absence (more properly, detection-nondetection) data in monitoring and habitat studies has increased rapidly in the past 10 years (Geissler and Fuller 1987, Buckland and Elston 1993, Fleishman et al. 2001, MacKenzie et al. 2002, Bailey et al. 2004), shifting interest from number of animals to number of sampling units occupied by animals. Monitoring site occupancy is often less expensive and time-consuming than monitoring abundance, making site occupancy a more attractive metric for large-scale monitoring programs (MacKenzie et al. 2002, Bailey et al. 2004). Royle and Nichols (2003) developed a statistical method for analyzing occupancy data to draw inferences not only about proportional occupancy of sampling units, but also site-specific abundance. The method uses information from the variation in detection probability to estimate the mean abundance per sampling site. By assuming a statistical distribution for patch (sampling site) abundance, mean abundance per patch can be estimated. Information about abundance exists in the detection-nondetection data from repeated visits, because it is more likely that at least one individual will be detected at a site with more individuals present than at a site with fewer individuals.

The Mountain Plover (Charadrius montanus) is one of 12 birds endemic to North American grasslands that has declined over the past century. Mountain Plovers were reported to have declined at an annual rate of $2.7 \%$ from 1966-1996 (Knopf 1996), resulting in significant declines in the continental breeding range of the species (Plumb et al. 2005). Historically, the breeding range of Mountain Plovers extended from southern Canada to Texas and New Mexico and from Nebraska to Utah (Knopf 1996). Today, the breeding range of plovers consists primarily of scattered, localized areas of Colorado, Montana, and Wyoming (Wunder et al. 2003). The decline in Mountain Plover populations has prompted conser- vation agencies to assess the spatial extent and contributing factors of the decline.

The continental population of Mountain Plovers was estimated at 8000-10 000 birds (Knopf 1996), but recent findings in Wyoming (Plumb et al. 2005) have led to a revised estimate of 11 000-14000 birds. Density estimates using distance sampling have been reported for specific locales including the Pawnee National Grassland (Knopf 1996) and South Park (Wunder et al. 2003) in Colorado. However, no population estimate exists for eastern Colorado, which is suggested to contain $50 \%-70 \%$ of the continental breeding population (Graul and Webster 1976, Knopf 1996, Kuenning and Kingery 1998).

Differences in landscapes and the distribution of Mountain Plovers throughout their range constrain the use of distance sampling. Mountain Plovers use a mosaic of public and private shortgrass prairie and private agricultural fields throughout eastern Colorado. Most private landowners allow access to walk transects through agricultural fields, but plovers are rarely detected at their initial locations because they actively avoid detection by humans (Wunder et al. 2003, Plumb et al. 2005). Plovers do not avoid vehicles, but vehicles cannot be driven across agricultural fields without causing crop damage and, therefore, monetary loss to private landowners. Thus, sampling in agricultural fields is commonly confined to field perimeters. Distance sampling along field perimeters (or roads) only provides estimates of animal density in the vicinity of the field perimeters, under- or overrepresenting (depending on the behavior of a species) density in the survey region (Buckland et al. 2001). In addition, distance sampling detection functions obtained from only sampling along roads are not valid because roads are not placed randomly with respect to plovers. Thus, density estimates from sampling along roads do not provide estimates of relative abundance, nor do they allow trends in abundance to be monitored (Buckland et al. 2001:295).

We tested the feasibility of the Royle and Nichols (2003) method to estimate abundance, occupancy rate, and detection probability of Mountain Plovers in the eastern plains of Colorado. The required data are plovers detected or not detected on a sampling site (hereafter, patch). Patch occupancy models allow abundance and detection probability to be estimated as functions of covariates. We tested the efficacy of patch occupancy sampling as a monitoring protocol for Mountain Plovers across three types of landscapes in eastern Colorado. As well as providing a monitoring protocol, patch occupancy methods can be used to explore important biological questions while fundamental differences in detection probability are taken into account.

\section{METHODS}

We used the method of Royle and Nichols (2003) to estimate abundance of Mountain Plovers during the 2003 breeding season in eastern Colorado. Our study site consisted of two specific locales with relatively high concentrations of breeding Mountain Plovers in eastern Colorado and was composed of three 
different habitat types: agricultural fields, shortgrass prairie grassland colonized by black-tailed prairie dogs (Cynomys ludovicianus, hereafter this habitat type is referred to as prairie dog colonies), and shortgrass grassland without black-tailed prairie dogs (hereafter, grassland). Agricultural fields are managed by individual farmers for crop production, primarily dryland wheat and spring fallow fields. The dominant vegetation of grassland and prairie dog colonies is buffalo grass (Buchloë dactyloides) or blue grama (Bouteloua gracilis) that may be grazed by domestic herbivores (cattle, sheep, or horses) during the breeding season.

Throughout our study area we surveyed a total of 82 patches: 26 in agricultural fields, 26 in grassland, and 30 in prairie dog colonies ( $\geq 80 \%$ of the patch had prairie dogs present). Patches were established by randomly selecting areas that contained (humandefined) suitable Mountain Plover habitat in the local study area prior to initiation of nesting activity. The patches were rectangular in shape and ranged from $50 \mathrm{~m}$ to $200 \mathrm{~m}$ on a side. The lower limit of $50 \mathrm{~m}$ was based on the fact that agricultural fields, especially dryland wheat fields, were not smaller than $50 \mathrm{~m}$ in width in our study sites. The $200 \mathrm{~m}$ limit for patch size was based on past research indicating detection probability is $\leq 0.20$ for Mountain Plovers at distances $\geq 200 \mathrm{~m}$ (Wunder et al. 2003). The actual area of each patch was defined by as many landscape characteristics as possible. If the boundaries of the patch could not be established from landscape features, flagging was used to delineate the patch. Thus, the size of each patch was measured, patch area was subsequently computed, and sightings of plovers during surveys were known to occur within the established patch.

Initial surveys began 12 May 2003 and were conducted at approximately five-day intervals until 4 July 2003. This time frame spans the egg-laying and incubation stages of Mountain Plover nesting activity in eastern Colorado (Knopf 1996). Each survey was $\geq 3 \mathrm{~min}$ and duration varied from patch to patch. The observer was allowed to leave the vehicle and walk along the edge of the patch, but not into the patch. Surveys were only conducted in weather conditions that were suitable for nest surveys (i.e., no rainfall or extreme wind). At each survey, the date, time of day, search time, observer, and number of plovers detected were recorded. Each patch was surveyed from six to 14 times.

\section{STATISTICAL ANALYSES}

The abundance estimation model has two types of parameters: 1) $r$ is the probability of detecting each individual Mountain Plover, and 2) $\lambda$ is the mean abundance of plovers per patch (Royle and Nichols 2003). We modeled both parameters as functions of patch- and survey-specific covariates. Detection probability, $r$, was modeled as a function of observer, habitat, search time, time of day, and time in the breeding season. Mean abundance was modeled as a function of habitat and patch size. Patch size was not used as an offset in modeling abundance because there was little variation in size relative to the area used by a plover. Due to the large number of possible model structures, the structure of $r$ was determined first, after which the structure of $\lambda$ was determined based on the top three modeled structures for $r$. Models were fit using maximum likelihood in SAS version 9.0 (SAS Institute 2003).

Model selection and inference was based on information-theoretic methods using Akaike's information criterion (AIC; Akaike 1973, Burnham and Anderson 2002) adjusted for small samples sizes $\left(\mathrm{AIC}_{c}\right.$; Hurvich and Tsai 1989). The number of patches, 82, was used as the sample size for $\mathrm{AIC}_{c}$. The goal of model selection is to identify a biologically meaningful model that explains much of the observed variability by including enough parameters to avoid substantial bias, but not so many that precision is lost (Lebreton et al. 1992, Burnham and Anderson 2002). We further used a measure of the difference in $\mathrm{AIC}_{c}$ between the best approximating model and all other models $\left(\triangle \mathrm{AIC} C_{c}\right.$; Lebreton et al. 1992, Burnham and Anderson 2002) to provide insight into the amount of uncertainty in model selection.

\section{RESULTS}

We detected a total of 184 plovers on $38(46 \%)$ of the 82 patches we surveyed during 807 patch survey visits. The number of patch visits for each of four observers ranged from 178 to 221 with the duration of each survey ranging from a minimum of 3 min up to maximum of $30 \mathrm{~min}$ if location of a nest needed confirmation. The size of the patches averaged 1.62 \pm 1.10 (SD) ha and ranged from 0.20 ha to 4.00 ha. The best model selected suggests mean abundance per patch varies among habitats, and the probability of detecting a plover varies by the amount of time the patch is searched, the time of the breeding season, and the observer (Table 1, Fig. 1). This model is greater than three times more likely to be the best approximating model than the second best model. Mountain Plover abundance was highest in prairie dog colonies, indistinguishably lower in agricultural fields, and considerably lower in grassland (Fig. 2). The probability of detecting a plover on a patch increased with the amount of time spent searching for plovers, varied among observers, and decreased later in the breeding season. Increasing the number of visits to a patch increased the probability of detecting a plover at least once, but the increase began to diminish after roughly seven visits for skilled observers (Fig. 1).

\section{DISCUSSION}

Our results suggest that estimating abundance of Mountain Plovers from patch occupancy data is feasible. Field protocols are relatively easy to implement and result in sample sizes large enough for estimation. Even though our results suggest that plovers were observed in higher concentrations in prairie dog colonies than the other habitats, further replication to assess our single-year findings would be desirable. Below we discuss our results with regard to determining the feasibility of the patch occupancy approach to estimating Mountain Plover abundance in eastern Colorado and specify needed improve- 
TABLE 1. Models for estimating Mountain Plover abundance from patch occupancy data in Colorado with Akaike weights greater than 0.01 . Detection probability, $r$, is modeled as a function of search time (st), time of the breeding season (brd), habitat type (habitat), whether plovers were previously known to be at a site (plover), and observers (obs). Mean abundance per sampling site, $\lambda$, is modeled as a function of habitat and patch size. Columns represent maximized log-likelihood $(\log -\mathcal{L})$, the number of estimated parameters $(K)$, the difference between the $\mathrm{AIC}_{c}$ of the best model and the current model $\left(\Delta \mathrm{AIC}_{c}\right)$, the model likelihood $(L)$, and the Akaike weight $\left(w_{i}\right)$.

\begin{tabular}{lccccc}
\hline \multicolumn{1}{c}{ Model } & \multicolumn{1}{c}{$\log -\mathcal{L}$} & $K$ & $\Delta \mathrm{AIC}_{c}{ }^{\mathrm{a}}$ & $L$ & $w_{i}$ \\
\hline$r($ st + brd + obs) $\lambda$ (habitat) & -244.23 & 9 & 0.00 & 1.00 & 0.47 \\
$r($ st + brd) $\lambda$ (habitat) & -248.36 & 6 & 2.26 & 0.32 & 0.15 \\
$r($ st + brd + obs) $\lambda$ (habitat + size) & -244.48 & 10 & 2.51 & 0.29 & 0.13 \\
$r($ st + habitat $) \lambda()$. & -249.64 & 5 & 2.83 & 0.24 & 0.10 \\
$r($ st + brd + obs) $\lambda()$. & -249.44 & 6 & 4.42 & 0.11 & 0.05 \\
$r($ st + brd + plover) $\lambda$ (habitat) & -248.45 & 7 & 4.45 & 0.11 & 0.05 \\
\hline
\end{tabular}

a The minimum $\mathrm{AIC}_{c}$ value was 506.45.

ments to make logical biological inferences from this approach.

A potential problem exists with extrapolating our results to a larger area. First, we only evaluated this method in areas of high plover concentrations. Therefore, the abundance of Mountain Plovers is likely not representative of a larger area. Second, if birds move on and off patches, the assumption of closure across sampling occasions is violated. Therefore, detection probability becomes confounded with occupancy on the current sampling occasion and abundance must be interpreted as the total number of plovers using the patch during the study. If that estimate of abundance is then extrapolated to all of eastern Colorado, for example, the total abundance of plovers will be overestimated. This problem is analogous to temporary emigration in capture-recapture studies (Kendall et al. 1997). There, a "super- population" is defined as the population of animals that uses a given area over the duration of the study. The idea of a superpopulation can be used to compare the number of plovers at the patch level across the survey period. Using multiple observers or shorter periods between observations can help minimize closure violations.

We observed more plovers per patch in prairie dog colonies than the other two habitat types during the 2003 breeding season, but only slightly more than in agricultural fields. Mountain Plovers selectively nest in black-tailed prairie dog colonies in Montana, especially in southern Phillips County (Knowles et al. 1982, Knowles and Knowles 1984, Olson and Edge 1985, Dinsmore 2001). In eastern Colorado, the association between prairie dogs and plovers is relatively unknown. Previous studies have suggested that the influence of prairie dog colonies on habitat

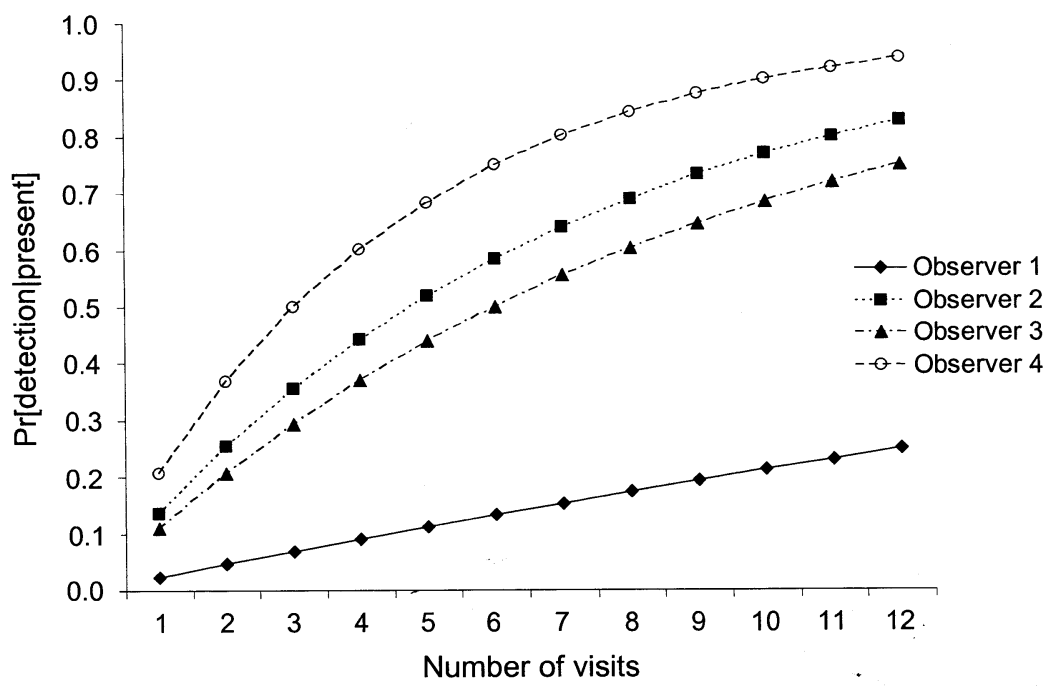

FIGURE 1. The change in the probability of detecting a Mountain Plover on at least one visit given a plover is present in the sampled site by observer across a range of number of visits. 


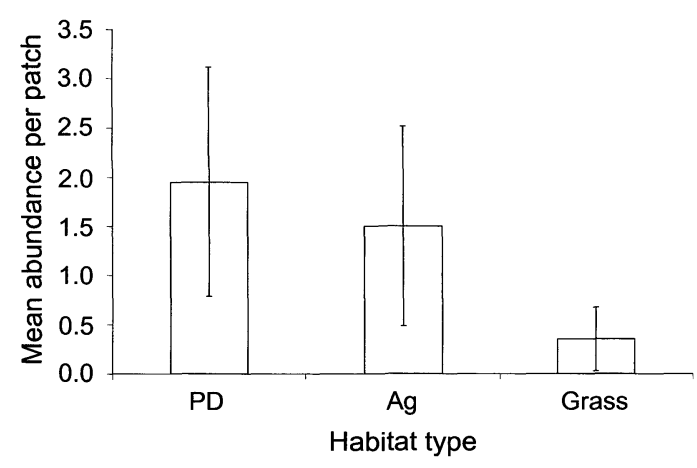

FIGURE 2. Estimated Mountain Plover abundance per patch (sampling site) and $95 \%$ confidence intervals in prairie dog towns (PD), agricultural fields $(\mathrm{Ag})$ and grassland (Grass) in eastern Colorado.

choice of grassland birds may be related to precipitation (Barko et al. 1999, Winter et al. 1999a, 1999b). Particularly during wet years in shortgrass prairie, when grasses are taller, prairie dog colonies and their associated vegetation communities become more distinctive (Smith and Lomolino 2004) and may serve as refugia for breeding plovers.

The abundance of Mountain Plovers in agricultural patches was only slightly lower than in prairie dog patches. Similar findings using density estimates have been observed during the summer (i.e., breeding season) in the Oklahoma Panhandle (Smith and Lomolino 2004). Mountain Plovers prefer landscapes with short vegetation providing high visibility and $\geq 30 \%$ exposed bare ground for nest construction (Knopf and Miller 1994, Knopf and Rupert 1999). These vegetation conditions describe both fallow and dryland wheat fields during the Mountain Plover breeding period in eastern Colorado. To thoroughly test differences in Mountain Plover abundance in shortgrass prairie habitat types in eastern Colorado, we suggest studies that use a probability-based sampling scheme to select survey patches, along with the field and analytical methods used in this study. We suggest that the probability-based sampling scheme include a higher number of patches in habitats known to have plovers and fewer (but some) patches in habitats in which plovers are not suggested to be present; i.e., a sampling scheme that selects patches based on the probability that the habitat supports plovers (an unequal probability-based sampling scheme).

\section{MONITORING}

One of the goals of conservation efforts is to maintain regional species diversity by preventing local species extinctions. Preventing local extinctions requires the preservation of habitat features that maintain stable or increasing populations of all indigenous species. This task is challenging in the face of increasing anthropogenic changes to the environment and limited information on the effects of environmental perturbations on populations. Limited financial resources and personnel prevent intensive monitoring of all populations. Consequently, biologists have tried to maintain regional biodiversity by focusing limited resources on conserving species, populations, or habitats at the highest risk of decline. This approach is reasonable, but relies on timely identification of populations or habitats at risk. Broad-scale monitoring programs provide one way to identify populations at high risk of decline. To be most effective, programs should monitor parameters that are sensitive to environmental disturbance and provide warning signals indicative of population decline. Early detection is important because reversing declining population trends can take decades (Green and Hirons 1991).

The probability of detecting a plover on at least one visit given a plover was present varied greatly by observer. Given this variation and the overall low probability of detecting a plover on a single visit, we suggest that at least five visits be conducted. This would give a skilled observer a probability of about 0.5 of detecting a plover in 5 min. MacKenzie and Royle (2005) provide details on optimizing the design of occupancy studies.

While the repeated site visits used in this protocol require more effort than a single visit, the increased information gained is useful. Some investigators may view repeated visits as an impediment to using this method, but it is impossible to obtain an estimate of site occupancy (abundance) when sites are only visited once without auxiliary information about detectability. We view accounting for detection probability as imperative for inference to be made about wildlife populations. Given that distance sampling was not feasible and multiple observers were not available at a single site, repeated visits to each patch were an economically feasible alternative and yielded information about detection probability. Wherever possible, we advocate collecting data (e.g., distance, multiple observer counts) other than detection-nondetection to estimate abundance. Such sampling schemes provide more information about animal abundance, especially when abundance is highly variable across space. Combining the estimation of a state variable, such as abundance, with a good sampling design allows biological questions to be answered in addition to monitoring trends. For rare species such as Mountain Plovers, the patch occupancy methods of Royle and Nichols (2003) provide meaningful insight into the relative population dispersion of a local species on the landscape.

We sincerely thank the landowners throughout eastern Colorado who provided access to their lands. We thank C. Mettenbrink, S. Musgrave, and L. Smythe for field assistance. Financial and logistical support were provided by the Colorado Farm Bureau, Colorado Division of Wildlife, U.S. Fish and Wildlife Service, and U.S. Geological Survey. We thank Kate Huyvaert for her efforts with the Spanish abstract translation.

\section{LITERATURE CITED}

AKAIKE, H. 1973. Information theory as an extension of the maximum likelihood principle, p. 267-281. 
In B. N. Petrov and F. Csaki [EDS.], Second international symposium on information theory. Akademiai Kiado, Budapest, Hungary.

Bailey, L. L., T. R. Simmons, AND K. H. Pollock. 2004. Estimating site occupancy and species detection probability parameters for terrestrial salamanders. Ecological Applications 14:692702.

$\rightarrow$ Barko, V. A., J. H. Shaw, And D. M. Leslie JR. 1999. Birds associated with black-tailed prairie dog colonies in southern shortgrass prairie. Southwest Naturalist 44:484 489 .

Buckland, S. T., D. R. Anderson, K. P. BurnHAM, J. L. LAAKE, D. L. BORCHERS, AND L. THOMAS. 2001. Introduction to distance sampling: estimating abundance of biological populations. Oxford University Press, Oxford, UK.

$\rightarrow$ Buckland, S. T., AND D. A. Elston. 1993. Empirical models for the spatial distribution of wildlife. Journal of Applied Ecology 30:478-495.

BurnhAM, K. P., AND D. R. ANDERSON. 2002. Model selection and multimodel inference $\rightarrow$ a practical information-theoretic approach. 2nd ed. Springer-Verlag, New York.

Dinsmore, S. J. 2001. Population biology of Mountain Plovers in southern Phillips County, Montana. Ph.D. dissertation, Colorado Stat $\rightarrow$ University, Fort Collins, CO.

$\rightarrow$ Fleishman, E., R. MaC Nally, J. P. FAy, AND D. D. MURPHY. 2001. Modeling and predicting species occurrence using broad-scale environmental variables: an example with butterflies of the Great Basin. Conservation Biology 15: 1674-1685.

Geissler, P. H., AND M. R. Fuller. 1987. Estimation of the proportion of area occupied by an animal species. Proceedings of the Section of Survey Research Methods of the American Statistical Association 1986:533-538.

$\rightarrow$ Graul, W. D., AND L. E. WebsTER. 1976. Breeding status of the Mountain Plover. Condor 78:265-267.

Green, R. E., AND G. J. M. Hirons. 1991. Tht $\rightarrow$ relevance of population studies to the conservation of threatened birds, p. 594-633. In C. M. Perrins, J.-D. Lebreton, and G. J. M. Hiron:
[EDS.], Bird population studies: relevance to conservation and management. Oxford University Press, Oxford, UK.

$\rightarrow$ Hurvich, C. M., AND C.-L. TsaI. 1989. Regressior $\rightarrow$ and time series model selection in small samples. Biometrika 76:297-307.

$\rightarrow$ Kendall, W. L., J. D. Nichols, AND J. E. Hines. 1997. Estimating temporary emigration using capture-recapture with Pollock's robust design Ecology 78:563-578.

KNOPF, F. L. 1996. Mountain Plover (Charadrius montanus). In A. Poole and F. Gill [EDS.], The birds of North America, no. 211. The Academy of Natural Sciences, Philadelphia, PA, and Thi American Ornithologists' Union, Washington, DC.

$\rightarrow$ KNOPF, F. L., AND B. J. Miller. 1994. Charadrius montanus-montane, grassland, or bare-ground plover? Auk 111:504-506.
KNOPF, F. L., AND J. R. RUPERT. 1999. Use of cultivated fields by breeding Mountain Plovers in Colorado. Studies in Avian Biology 19:81-86.

KnOWles, C. J., AND P. R. KNOWLes. 1984. Additional records of Mountain Plovers using prairie dog towns in Montana. Prairie Naturalist 16:183-186.

Knowles, C. J., C. J. Stoner, AND S. P. Gieb. 1982. Selective use of black-tailed prairie dog towns by Mountain Plovers. Condor 84:71-74.

KuenNing, R. R., AND H. E. KINGERY. 1998. Mountain Plover, p. 170-171. In H. E. Kingery [ED.], Colorado breeding bird atlas. Colorado Bird Atlas Partnership and Colorado Division of Wildlife, Denver, CO.

Lancia, R. A., J. D. Nichols, and K. H. Pollock. 1994. Estimating the number of animals in wildlife populations, p. 215-253. In T. Bookhout [ED.], Research and management techniques for wildlife and habitats. The Wildlife Society, Bethesda, MD.

Lebreton, J.-D., K. P. Burnham, J. Clobert, AND D. R. ANDERSON. 1992. Modeling survival and testing biological hypotheses using marked animals: a unified approach with case studies. Ecological Monographs 62:67-118.

MacKenzie, D. I., J. D. Nichols, G. B. Lachman, S. Droege, J. A. Royle, And C. A. LANGTimm. 2002. Estimating site occupancy rates when detection probabilities are less than one. Ecology $83: 2248-2255$

MacKenzie, D. I., AND J. A. Royle. 2005. Designing occupancy studies: general advice and allocating survey effort. Journal of Applied Ecology 42:1105-1114.

MacKenzie, D. I., J. A. Royle, J. A. Brown, AND J. D. NICHOLS. 2004. Occupancy estimation and modeling for rare and elusive populations, p. 149-172. In W. L. Thompson [ED.], Sampling rare or elusive species: concepts, designs and techniques for estimating population parameters. Island Press, Washington, DC.

Olson, S. L., AND D. EDGE. 1985. Nest site selection by Mountain Plovers in northcentral Montana. Journal of Range Management 38:280-282.

Plumb, R. E., F. L. KNOPF, AND S. H. Anderson. 2005. Minimum population size of Mountain Plovers breeding in Wyoming. Wilson Bulletin 117:15-22.

Pollock, K. H., J. D. Nichols, T. R. Simons, G. L. FARNSWORTH, L. L. BAILEY, AND J. R. SAUER. 2002. Large scale wildlife monitoring studies: statistical methods for design and analysis. Environmetrics 13:105-119.

Royle, J. A., AND J. D. Nichols. 2003. Estimating abundance from repeated presence-absence data or point counts. Ecology 84:777-790.

SAS InSTITUTE. 2003. SAS version 9.0. SAS Institute, Inc., Cary, NC.

Smith, G. A., AND M. V. Lomolino. 2004. Blacktailed prairie dogs and the structure of avian communities on the shortgrass plains. Oecologia 138:592-602.

Thompson, S. K. 1992. Sampling. John Wiley and Sons, New York. 
Winter, S. L., J. F. CUlly JR., AND J. S. Pontius. 1999a. Influence of prairie dog colonies and climatic variation on bird communities in Kansas shortgrass prairie, p. 374. In J. Thorpe, T. A. Steeves, and M. Gollop [EDS.], Proceeding: of the fifth prairie conservation and endangered species conference. Provincial Museum of Alberta, Edmonton, Alberta.

Winter, S. L., J. F. CUlly JR., AND J. S. Pontius. $1999 \mathrm{~b}$. Influence of prairie dogs on vegetation in Kansas shortgrass prairie, p. 375-379. In J.
Thorpe, T. A. Steeves, and M. Gollop [EDS.], Proceedings of the fifth prairie conservation and endangered species conference. Provincial Museum of Alberta, Edmonton, Alberta.

Wunder, M. B., F. L. Knopf, and C. A. Pague. 2003. The high elevation population of Mountain Plovers in Colorado. Condor 105:654-662.

YocCOZ, N. G., J. D. NiChOLS, AND T. BOUlinier. 2001. Monitoring of biological diversity in space and time: concepts, methods, and designs. Trends in Ecology \& Evolution 16:446-453.

\title{
RELATIONSHIP BETWEEN ASPEN HEARTWOOD ROT AND THE LOCATION OF CAVITY EXCAVATION BY A PRIMARY CAVITY-NESTER, THE RED-NAPED SAPSUCKER
}

\author{
NeIl Losin ${ }^{1,5}$, Chris H. Floyd ${ }^{2}$, Todd E. SchweItzer ${ }^{3}$, AND SARAH J. Keller ${ }^{4}$ \\ ${ }^{1}$ Section of Evolution and Ecology, University of California, One Shields Avenue, 2320 Storer Hall, \\ Davis, CA 95616 \\ ${ }^{2}$ Department of Biology, Phillips Hall 330, University of Wisconsin-Eau Claire, Eau Claire, WI 54701 \\ ${ }^{3} 308$ S. $12^{\text {th }}$ St., Gunnison, CO 81230 \\ ${ }^{4}$ Biology Department, University of New Mexico, MSC03 2020, Albuquerque, NM 87131
}

Abstract. We investigated nest-hole excavation by the Red-naped Sapsucker (Syphrapicus nuchalis) in aspen (Populus tremuloides) woodlands in western Colorado. Sapsuckers excavate nest cavities primarily in aspens infected with a heartwood rot fungus (Phellinus tremulae), which softens the heartwood of infected trees. We assessed the interior condition of fungus-infected aspen trunks by extracting wood samples with an increment corer to determine whether sapsuckers chose nest-hole locations based on the extent of healthy sapwood remaining. Comparing fungus-infected trees with and without cavities, cavity-bearing trees had thinner healthy sapwood. The depth of healthy sapwood also varied with compass direction, being thinnest on the south sides of fungus-infected aspens. Cavity entrance orientations were significantly biased to the southsoutheast, corresponding with the directional bias in heartwood rot. These results suggest that the depth of healthy sapwood, and hence excavation effort, may be important in determining nest hole location for the Red-naped Sapsucker.

Key words: cavity-nesting birds, heartwood fungus, nest-site selection, Phellinus tremulae, Populus

Manuscript received 9 September 2005; accepted 28 April 2006

${ }^{5}$ E-mail: njlosin@ucdavis.edu tremuloides, Red-naped Sapsucker, Syphrapicus nuchalis.

\section{Relación entre un Hongo de Populus} tremuloides y la Ubicación de Excavaciones de Syphrapicus nuchalis, un Ave que Nidifica en Cavidades Primarias

Resumen. Investigamos la excavación de cavidades de nidificación por parte de Syphrapicus nuchalis en bosques de Populus tremuloides en el oeste de Colorado. Esta especie excava las cavidades principalmente en árboles infectados con el hongo Phellinus tremulae, el cual ablanda la madera. Evaluamos la condición interna de los troncos de los árboles infectados mediante la extracción de muestras de madera con un barreno de incremento para determinar si las aves eligen la localización de las cavidades basadas en la magnitud de restos de madera saludable. Comparando los árboles infectados con hongos con y sin cavidades, los árboles que presentaron cavidades tuvieron una madera saludable más delgada. La profundidad de la madera saludable también varió con la orientación cardinal, siendo más delgada en las caras sur de los árboles infectados. La orientación de la entrada de las cavidades estuvo significativamente sesgada hacia el sur-sureste, correspondiendo con el sesgo direccional del hongo. Estos resultados sugieren que la profun- 